should be transferred at the earliest opportunity from the centre to affiliated casualty base hospitals in the outer areas.

\section{The Palæontographical Society}

Ar the annual meeting of the Palæontographical Society held in the rooms of the Geological Society on March 31, the Council reported that the Society's ninety-first annual volume had been issued during the past year. This volume contains the first part of a new monograph on the Carboniferous Rugose Corals of Scotland by Dr. Dorothy Hill. Largely based on the extensive and oft-quoted material studied by James Thomson and afterwards disorganized by the fire in the Kilmarnock Museum in 1909 , this monograph introduces considerable simplification in systematic nomenclature. Further instalments of the monographs on Cambrian trilobites by Mr. P. Lake and on corallian ammonites by Dr. W. J. Arckell are also included in this volume. The work of the Society in publishing illustrations and descriptions of fossils collected in Great Britain has been materially assisted by an allotment of $£ 100$, from the Government Publication Grant administered by the Royal Society, towards the issue of the monograph on corallian ammonites. Other donations mentioned in the report include sums of money received from the Colston Research Fund of the University of Bristol and from Miss Mary S. Johnston. Monographs which are also in progress include Pleistocene Mammalia (Prof. S. H. Reynolds), Cretaceous Belemnites (Prof. H. H. Swinnerton, Gault Ammonoidea (Dr. L. F. Spath), Great Oolite Brachiopoda (Dr. Helen Muir-Wood), Dendroid Graptolites (Dr. O. M. B. Bulman) and Palæozoic Asterozoa (Dr. W. K. Spencer). The following officers were elected for the ensuing year: President, Sir A. Smith Woodward; Treasurer, W. E. F. Macmillan; Secretary, Dr. C. J. Stubblefield.

\section{Mayan Chronology: New Evidence}

A JorN' expedition of the Smithsonian Institution, Washington, and the National Geographic Society, which is engaged in the excavation of a site at Tres Zapotes, in the State of Vera Cruz, southern Mexico (according to a communication issued by Science Service, Washington), has discovered a date monument which, it is anticipated, will settle a muchdebated question of the authentic age of the reputedly earliest known dated Mayan object, and at the same time determine how and when the ancient Maya first spread over Central America. The site at Tres Zapotes, it is to be noted, is at least one hundred miles west of what had hitherto been believed to be the Mayan zone. Reports of the early results of excavation indicate that the site at Tres Zapotes is early; but the dating of the recently discovered monument is in the so-called 'short' style, which has generally been regarded as a late invention. Apart from its intrinsic interest, the question whether this style of dating was or was not in use in the early period of Mayan civilization is of importance in its bearing on the age of the famous jado statuette of a priest now in the National Museum, Washington.
This statuette bears a dating equivalent, on the Spinden correlation, to May 16, 98 B.C., and if this be taken at its face value, the statuette is the oldest known dated Mayan object. The date, however, is written according to the 'short' system, and question, therefore, has been raised whether the dating is contemporary, or was added in a later period, or whether, indeed, the statuette itself may not be an archaistic piece. Dr. Matthew W. Stirling, who is in charge of the excavation, has summoned a conference of archæologists to be held on the site, to discuss whether they confirm his conclusion that the newly discovered monument is 'early'.

\section{Eoliths}

A communication from Mr. A. S. Barnes traverses the arguments put forward by Mr. J. Reid Moir for the human origin of the pre-Crag implement (see NATURE of January 28, p. 151) and deals seriatim with the characters upon which he relies. The problem of the differences between natural and human flaking is discussed by Mr. Barnes at length in the current issue of the American Anthropologist (41, 1, 1939, p. 99). He there maintains that the arguments for the human origin of pre-Crag implements are for the most part purely subjective, while it has been shown that purely natural forces are able to produce flaking similar to that on eoliths, and further, that the flaking on eoliths differs from that on human work. Although attempts have been made to formulate objective differences between the flake detached by man and those detached by natural agencies, such as 'resolved flakes' and flakes with certain other characteristics, these effects, Mr. Barnes holds, are found on flake fractures by fortuitous pressure as well as by man. After recapitulating the factors operating in natural and artificial fracture, Mr. Barnes goes on to suggest that a criterion of human workmanship, readily measurable and common to both classes of flaking, natural and artificial, is to be found in the angle platform-scar, which he defines as the dihedral scar formed by the intersection of the surface on which the blow has been struck, or pressure applied, and the surface of the scar left by the flake removed. As the result of an investigation of a large number of specimens by this method it has been found that an industry, or supposed industry, may be regarded as of human origin if not more than 25 per cent of the angles platform-scar are obtuse, that is, $90^{\circ}$ and over. None of the eoliths examined by Mr. Barnes complies with this criterion, and, he maintains, cannot therefore be considered to be of human origin.

\section{Encouraging Inventions}

The Paris International Trade Fair will be held during May 13-29. An interesting feature is the Inventions Competition (Concours d'Inventions), which is open and free to every inventor. An invention of any type may be entered. It may take the form of a new apparatus or device or it may be an improvement which can be incorporated in existing machinery or material. There is a strict 
limitation that the invention must not have been exhibited for any other competition. Each competitor must also attach to his entry form a copy of his patent specification, or, if the invention be not patented, a notice setting forth its aims and functions and, when possible, a résumé of its technical qualifications. If possible, actual models (in working order) are to be submitted, but if this cannot be done, permission may be obtained for their presentation by means of a plan. The jury decides whether the plan submitted is sufficiently explicit in itself to convey to experts, and to the public, a clear representation of the functions and operation of the invention. The total area allotted to each exhibit will as a rule not exceed one square metre, but by special application to the committee larger models may be exhibited. All inventions entered for the competition are dis. played in a special hall for the duration of the Fair and should be forwarded so as to arrive not later than May 5, addressed Foire de Paris, Concours d'Inventions, Porte de Versailles, Paris 15. The exhibits are classified under many headings, including engineering, medical apparatus, domestic economy, games, travel and camping, office equipment, publicity and education. Competitors whose inventions are not patented may apply for a certificate of guarantee affording protection in France for a period of twelve months from the opening date of the Fair. Entry forms can be obtained at the London Office of the Foire de Paris, 17 Tothill Street, Westminster, S.W.1, and must be completed by March 31 .

\section{Combustible Material in Electric Power Stations}

EARLY in this century, after a fire at Bristol, rubber-covered cables for switchboard work were rarely used. The recent inquiry on the fire at the Kingston Power Station should accelerate the demand for the use of non combustible materials alone in main power stations. It was stated in evidence that about 850 gallons of inflammable oil and about $14,000 \mathrm{lb}$. of solid compound fed the flames. Fires due to oil have been perhaps more numerous in America and Germany than in Great Britain; but recent events show the necessity of getting control of a fire in a power station at the earliest possible moment. The modern oil circuit-breaker (switch) has proved very trustworthy in practice. At its rated eapacity it will clear any electric faults with certainty; but in very exceptional circumstances it may fail. The chiefs of supply stations are now paying great attention to the problem of oil-less circuit breakers. Several foreign makers have for the last few years been successfully producing oil-less breakers, particularly the A.E.G. Co. in Berlin, the BrownBoveri Co. and the Oerlikon Co. in Switzerland. The A.E.G. Co. manufactures a special breaker called a chemical resin breaker for service in unattended substations where the air-blast type could not receive adequate supervision and maintenance. A very profitable and urgent line of inquiry for the industrial research worker would be to try to discover noncombustible liquids and solids of high insulating value for transformers, switches and electric wires. Some fairly satisfactory liquids and compounds have been found, but their cost at present is far too high for use in bulk. It is all a matter of finance. Textile glass has recently been invented. It seems probable that as a wrapping for electric wires it will have a great future.

\section{Agricultural Research and the Farmer}

A Broadsheet "Bringing Science to the Farm" issued by P E P (Political and Economic Planning) directs attention to defects in the present system of putting the results of agricultural research at the disposal of the farmer. Some of the difficulties are familiar in other attempts at the popularization of scientific discoveries, notably the superimposition of lecturing on research. Not only does such work impede actual research, but also research ability is by no means invariably linked to lecturing ability, and poor exposition may retard rather than help the spread of agricultural knowledge. The broadsheet urges a thorough overhaul of the provincial advisory service, which is not only seriously understaffed but has lagged behind the rapid diversification and specialization of the sciences concerned. Inadequate arrangements exist for liaison between the provincial advisers and research institutes not situated at their centre, or within their province as well as between the research institute and the farmer. The efficiency of the advisory service moreover depends primarily on the rateable value of the county and is controlled by the county agricultural committees, which cannot be expected to have the same scientific outlook and aims as the research and provineial advisory workers. County organizers do not always refer to the provincial advisers' problems which are beyond their own capacity, and the county organizer is often laden with many other duties besides advisory work. The broadsheet criticizes the annual reports of the research stations from the point of view of propaganda and also the manner of distribution of the official leaflets for farmers issued by the Ministry of Agriculture as well as the meagre use made of films, and lays special stress on the place of the educational services as the fundamental link between research and practice.

\section{Colloquium on Sex Hormones}

IN June 1937 a colloquium on sex hormones was held in Paris under the auspices of La Fondation Singer-Polignac. This colloquium was attended by men of science from France, Denmark, the United States, Canada, Great Britain, etc. The meeting lasted ten days, morning and afternoon sessions being held for the reading of papers on most days. The wide international representation of active investigators led to great interest being taken in the papers and to vigorous discussion. The papers presented, together with summaries of the discussions, were afterwards published in one volume for private circulation. They have now been republished in five numbers, each containing five papers, in the series of "Actualités Scientifiques et Industrielles" (Paris : Hermann et Cie). The first number appears under the general title "Les Propriétés des Hormones Sexuelles". The second number deals with "Ovula. 